\title{
"Role of tourist motivation as mediating variable on visitor decisions at Indonesian tourism village"
}

\begin{tabular}{|c|c|c|}
\hline AUTHORS & $\begin{array}{l}\text { Martaleni Martaleni (iD } \\
\text { Ernani Hadiyati (D) } \\
\text { Yussi Isna Pertiwi } \\
\text { Ni Nyoman Kerti Yasa (iD) }\end{array}$ & \\
\hline ARTICLE INFO & \multicolumn{2}{|c|}{$\begin{array}{l}\text { Martaleni Martaleni, Ernani Hadiyati, Yussi Isna Pertiwi and Ni Nyoman Kerti } \\
\text { Yasa (2021). Role of tourist motivation as mediating variable on visitor decisions } \\
\text { at Indonesian tourism village. Innovative Marketing , 17(3), 88-98. } \\
\text { doi:10.21511/im.17(3).2021.07 }\end{array}$} \\
\hline DOI & \multicolumn{2}{|c|}{ http://dx.doi.org/10.21511/im.17(3).2021.07 } \\
\hline RELEASED ON & \multicolumn{2}{|l|}{ Friday, 20 August 2021} \\
\hline RECEIVED ON & \multicolumn{2}{|l|}{ Friday, 11 June 2021} \\
\hline ACCEPTED ON & \multicolumn{2}{|l|}{ Tuesday, 03 August 2021} \\
\hline LICENSE & \multicolumn{2}{|c|}{$\begin{array}{l}\text { This work is licensed under a Creative Commons Attribution } 4.0 \text { International } \\
\text { License }\end{array}$} \\
\hline JOURNAL & \multicolumn{2}{|l|}{ "Innovative Marketing " } \\
\hline ISSN PRINT & \multicolumn{2}{|l|}{$1814-2427$} \\
\hline ISSN ONLINE & \multicolumn{2}{|l|}{$1816-6326$} \\
\hline PUBLISHER & \multicolumn{2}{|c|}{ LLC "Consulting Publishing Company "Business Perspectives" } \\
\hline FOUNDER & \multicolumn{2}{|c|}{ LLC "Consulting Publishing Company "Business Perspectives" } \\
\hline$\sigma^{0}$ & & 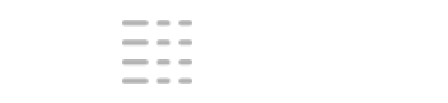 \\
\hline NUMBER OF REFERENCES & NUMBER OF FIGURES & NUMBER OF TABLES \\
\hline 80 & 1 & 4 \\
\hline
\end{tabular}

(c) The author(s) 2021. This publication is an open access article. 


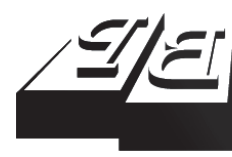

\section{BUSINESS PERSPECTIVES}

(O)

LLC "CPC "Business Perspectives"

Hryhorii Skovoroda lane, 10, Sumy, 40022, Ukraine

www.businessperspectives.org
Received on: $11^{\text {th }}$ of June, 2021 Accepted on: $3^{\text {rd }}$ of August, 2021 Published on: $20^{\text {th }}$ of August, 2021

(C) Martaleni Martaleni, Ernani Hadiyati, Yussi Isna Pertiwi, Ni Nyoman Kerti Yasa, 2021

Martaleni Martaleni, Ph.D., Associate Professor, Management Department, University of Gajayana Malang, Indonesia. (Corresponding author)

Ernani Hadiyati, Ph.D., Professor, Management Department, University of Gajayana Malang, Indonesia.

Yussi Isna Pertiwi, Graduated Student, Management Department, University of Gajayana Malang, Indonesia.

Ni Nyoman Kerti Yasa, Ph.D., Professor, Faculty of Economics and Business, University of Udayana, Indonesia.
This is an Open Access article, distributed under the terms of the Creative Commons Attribution 4.0 International license, which permits unrestricted re-use, distribution, and reproduction in any medium, provided the original work is properly cited.

Conflict of interest statement: Author(s) reported no conflict of interest

Martaleni Martaleni (Indonesia), Ernani Hadiyati (Indonesia), Yussi Isna Pertiwi (Indonesia), Ni Nyoman Kerti Yasa (Indonesia)

\title{
ROLE OF TOURIST
}

MOTIVATION AS MEDIATING

VARIABLE ON VISITOR

\section{DECISIONS AT INDONESIAN TOURISM VILLAGE}

\begin{abstract}
The tourism sector has become a truly global force for promoting economic growth and development. Therefore, the study of tourism has become an interesting topic for researchers lately. On the other hand, local tourism, generally in developing countries, is often neglected by academics and policymakers. For this reason, this study aims to examine and analyze the role of tourist motivation in mediating accessibility, amenities, and attractions on visiting decisions. This study is a survey research with an explanatory method. The population is tourists who visit the tourism village of Bumiaji, Indonesia, in the low and busy seasons. The population is infinite and the number of respondents who were interviewed is 100 respondents; data were collected by distributing questionnaires to domestic tourists who came from outside the tourist village of Bumiaji, then the data were processed and analyzed using Warp Partial Least Squares. The findings indicate that the effect of accessibility on visiting decisions is not mediated by tourist motivation. This shows that the decision of tourists to visit can be directly influenced by the time and means of transportation available. Meanwhile, the influence of amenities and attractions on the decision to visit is mediated by the motivation of tourists. This means that amenities and attractions can influence a tourist's decision to visit if there is an urge from tourist to relax or make friends or enjoy the culture at tourist attractions, etc.
\end{abstract}

\section{Keywords}

JEL Classification

\section{INTRODUCTION}

In general, the growth of the tourism industry has encouraged the acceleration of a country's economy the creation of more and better jobs and serving as a catalyst for innovation and entrepreneurship (Gelgel, 2006; Correia \& Pimpao, 2008; Pololikashvili, 2019; Celik \& Dedeoglu, 2019; Mak, 2004; Aksoy \& Kiyci, 2011; Marrocu \& Paci, 2013; Martaleni, 2017). This shows that the tourism sector is currently very dynamic, always providing new business opportunities as well as big challenges (Rodrigues et al., 2021) for increasing competitiveness through creative innovation in the tourism industry (Martaleni et al., 2019). Tourists as consumers, of course, have various kinds of needs and desires when visiting a tourism spot that needs to be the attention of the manager (Camilleri, 2019; Buhalis, 2000; Tajzadeh, 2013). The perception of visitors to support services differs according to the location of the tourist attraction (Jensen et al., 2017). It is necessary to adjust its tourism products to meet the expectations and needs of visitors (Happ et al., 2021).

The need to understand the motivation behind tourist behavior as consumers of a destination is very important (Correia \& Pimpao, 
2008; Kotler \& Keller, 2016; Kozak \& Kozak, 2018) because the results are useful for implementing marketing strategies or designs (Beritellia et al., 2020) which results in tourism sustainability (Kastenholz et al., 2018). If tourists' needs are met, tourists will be interested in making repeat visits and will even recommend other parties (Kotler et al., 2014). Offering good attributes will be able to influence tourist decisions to make tourism visits (Cakici \& Harman, 2007; Camilleri, 2019). Tourism development needs to have an important component, including tourism potential as a tourist attraction, accessibility, and basic facilities (Vareiro et al., 2021). Attractiveness can also be used as a factor forming a positive image of a tourist destination (Hernandez et al., 2021; Martaleni \& Gunadi, 2017) and is a very important factor for tourists in choosing a tourist destination (Faerber et al., 2021).

Studies on the influence of tourist attributes on tourist motivation to visit destinations have been carried out, including Dey et al. (2020), Correia and Pimpao (2008), Hasan et al. (2018), Reitsamer et al. (2016), and Simeon et al. (2017). The availability of tourist attributes in a tourist destination is an important component of such tourism that can have a positive impact both directly and indirectly on tourist satisfaction and loyalty (Teixeira et al., 2019; Bayih \& Singh, 2020; Faerber et al., 2021; Shaykh-Baygloo, 2021). However, there are still not many studies that show the role of tourist motivation as a mediation for the influence of accessibility, amenities, and attractions on tourists' decisions in visiting a destination, especially in tourism villages. Motivation is an important determinant of tourist behavior (Albayrak \& Caber, 2018). This shows that there is a research gap regarding the role of tourist motivation as a mediating variable between accessibility, amenities, and attraction towards visiting decisions.

\section{LITERATURE REVIEW AND HYPOTHESES DEVELOPMENT}

In studying tourism, it is crucial to determine important aspects in tourism marketing efforts and understand the motivation of tourists to make tourist visits (Camilleri, 2019; Pitana \& Dianta, 2009; Tajzadeh, 2013). Destination management has become a concern and contributed to the advancement of tourism research (Volgger et al., 2021). Destination characteristics and stakeholders play an important role in engaging tourists in the production of experiences (Karayilan \& Cetin, 2016). Socio-cultural and ecological dimensions as well as taking into account all stakeholders who participate in the tourism process are also important (Nadalipour et al., 2018).

In order to meet the needs, desires, and satisfaction of visitors, each tourist destination must pay attention to easy access, facilities, and support services. Tverijonaitea et al. (2018) stated that accessibility is one of the most important variables in planning tourism development in natural destinations. Camilleri (2019) and Lee (2015) explained that tourist satisfaction with the factory tour experience includes internal accessibility and external accessibility. Visitors prefer tourist destinations with good accessibility in minimizing travel time (Jin \& Weber, 2016; Bhulyan \& Darda, $2020)$. Tourists choose the main route based on travel time (Díez-Gutierrez \& Babri, 2020), also they have access to, require the accommodation of tourist objects, and engage in recreational activities (Camilleri, 2019). Visitors prefer tourist destinations with good accessibility that offer an additional level of enjoyment (Jin \& Weber, 2016; Bhulyan \& Darda, 2020). Tourists choose the main route based on travel time and street views (DíezGutierrez \& Babri, 2020).

Tourist attraction facilities are an important support to meet the needs and desires of tourists in enjoying tourist objects that must have the right amenities and facilities or be able to offer different products to satisfy tourists (Camilleri, 2019; Hasan et al., 2018; Lee, 2015). Wijaya et al. (2019) divided facilities into several groups, including public facilities and supporting facilities. Tourists view tourism destinations as a place to relax even though little information is available about facilities (Correia \& Pimpao, 2008). Facilities and cleanliness, destination familiarity, value for money and proximity to destinations, local attrac- 
tions, and supporting travel facilities are factors of interest to tourists in choosing international destinations that they want to visit (Wijaya et al., 2019).

Attractions are very important factors in choosing a tourist destination and have tremendous attractiveness to the economic impact (Faerber et al., 2021; Boom Liat et al., 2020; Simeon et al., 2017). Tourist attractions can be built from the features of natural tourism, cultural tourism, such as magic, authenticity, relaxation, discovery, and knowledge (Simeon et al., 2017; Martaleni, 2017; Camilleri, 2019). Originality has a stronger influence on the components of subjective attitudes and norms (Lee et al., 2020; Hakim \& Mulia, 2019; Bhulyan \& Darda, 2020), can even make tourists loyal to a tourist destination (Martaleni, 2014), and can even be used as a forming factor for a positive image of tourism destination (Martaleni \& Gunadi, 2017). In addition, a positive attitude towards an attractive destination leads to a higher intention to visit that destination (Al-Kwifi, 2015; Jin \& Weber, 2016). Meanwhile, service quality and tourist satisfaction are considered to have the greatest direct influence on destination loyalty (Quintal \& Polczynski, 2010; Shakoori \& Hosseini, 2019). Tourists can interpret cultural attractions in different ways (Boom Liat et al., 2020; Simeon et al., 2017). Tourism products can include urban (or city) tourism, seaside tourism, rural tourism, ecotourism, wine tourism, culinary tourism, health tourism, medical tourism, religious tourism, cultural (or heritage) tourism, sports tours, educational tours, and business tours (Camilleri, 2019).

Motivation is understood as a socio-psychological phenomenon, which is related to the internal and emotional aspects of the individual regarding the desire to escape, have rest, experience adventure and emotional arousal (Güzela et al., 2020). Tourism motivation is defined as a set of one's needs and attitudes to join in tourism activities (Pizam et al., 1979; Bideci \& Albayrak, 2016). Motivation is the driving force that causes a person to take action to meet their needs (Kotler \& Keller, 2016). Motivation is a determinant of a person's behavior (Bideci \& Albayrak, 2016). Generally, tourists come from different countries with different cultures, characteristics, and preferences for tourist products depending on their level of need (Celik \& Dedeoglu, 2019). Martaleni
(2014), Preko et al. (2019), and Hakim and Mulia (2019) concluded that the lowering of tourist motivation will be able to increase tourist satisfaction with tourist destinations. Tourism provides an experience that is different from everyday life, endowing tourists with a general sense of well-being (Wang et al., 2020) and it has a positive impact on satisfaction (Celik \& Dedeoglu, 2019) and tourists' intention to choose sustainable tourist attractions (Correia \& Pimpao, 2008; Mohaidin et al., 2017; Sie et al., 2021).

The process of making visiting decisions includes identifying problems, seeking information, evaluating information, making decisions, and post-purchase behavior (Kotler \& Keller, 2016). Making travel decisions is a part of an individual's life, which is influenced by many factors, such as culture, values, religion, and income (Hassani \& Moghavvemi, 2020). Bozic et al. (2017) explained that culture is the dominant factor in motivating to make tourist visits. Seo et al. (2018) stated that knowledge and subjective attitudes towards Korean food significantly influence the intention to visit Korean restaurants. To understand behavior, it is necessary to examine the complex interactions of the many elements that influence it (Moutinho, 1987).

Based on the theoretical and empirical studies review, a conceptual framework can be prepared as shown in Figure 1. In this study, three independent variables (accessibility, amenities, and attractions) were used, one intervening variable (tourist motivation) and one dependent variable (decision visiting). Furthermore, the influence of the variables of accessibility, amenities, and attractions directly on visiting decisions and the indirect influence through tourist motivation is investigated.

Based on this conceptual framework, it is hypothesized:

H1: Accessibility have a significant direct effect on the tourist motivation.

H2: Amenities have a significant direct effect on the tourist motivation.

H3: Attraction have a significant direct effect on the tourist motivation. 


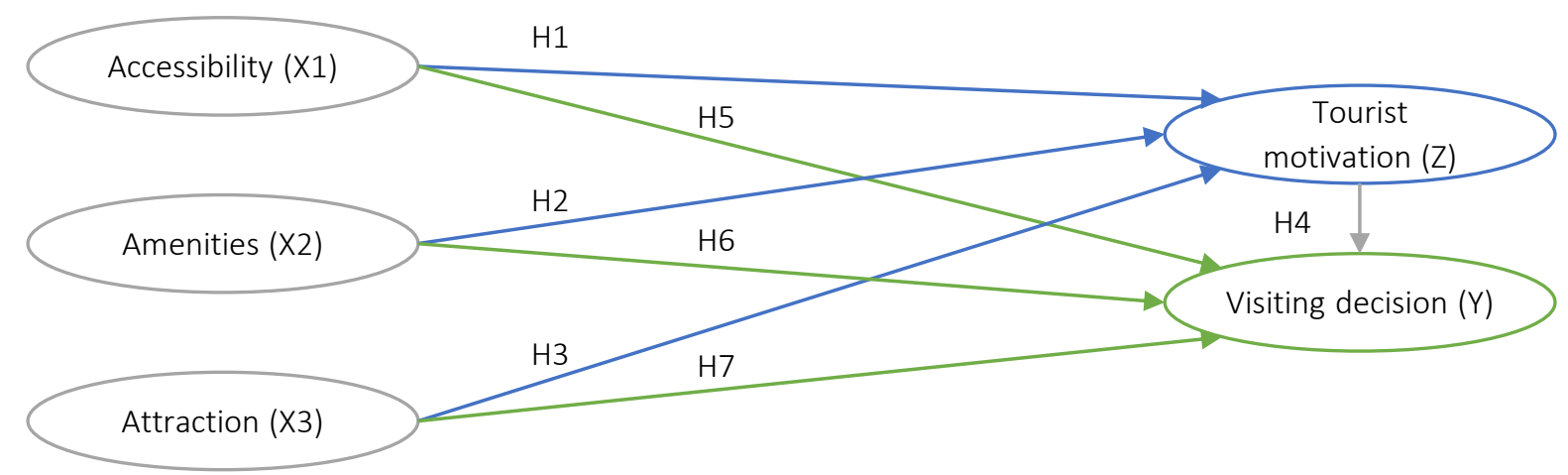

Figure 1. Conceptual framework

H4: $\quad$ Tourist Motivation have a significant direct effect on the visiting decision.

H5: Accessibility have a significant direct effect on the visiting decision.

H6: Amenities have a significant direct effect on the visiting decision.

H7: Attraction have a significant direct effect on the visiting decision.

\section{METHODOLOGY}

This study uses a quantitative research method with an explanatory type, namely a method to obtain an explanation of the relationship (causality) between variables through hypothesis testing (Cresweel, 2014; Malhotra, 2007; Solimun et al., 2017). The location is a tourist destination in Bumiaji village with 4 tourist objects, namely Crystal Guava Agro Tourism, Etawa Madukara Goat Farm, Slamet Cultural Omah, and Bumi Kitiran. The population is all domestic tourists who visit the tourism village of Bumiaji and come from outside this tourism village. The population in the study is scattered and difficult to know with certainty. The size of the sample used is 100 , this is based on the opinion of Malhotra (2007) who says that the appropriate sample size is 100-200. Determination of the sample using judgment sampling (Malhotra, 2007; Hair et al., 2014) with the criteria of respondents used as samples are (1) aged above or equal to 17 years; (2) come from outside the tourism village of Bumiaji. The variables used to consist of 3 (three) types, namely independent variables, mediating varia- bles, and dependent variables. The independent variables consist of accessibility, amenities, and attractions. Accessibility is measured by 4 (four) indicators, namely: ease of access, road quality, travel time, and transportation. Amenity is measured by 6 (six) indicators, namely: the presence of places to eat and drink, lodging facilities, gazebos or benches to enjoy objects, gift shops, toilets, parking areas. Attractions are measured by 3 (three) indicators, namely uniqueness, beauty, and authenticity. The mediating variable is the motivation of tourists as measured by 4 (four) indicators, namely: physical motivation, culture, social aspects, and fantasy. The dependent variable is the decision to visit that is measured by 5 (five) indicators, namely: convenience, facilities, image, motive, and knowledge. The type of data used is qualitative data sourced from primary data and collected using questionnaires given to tourists when tourists are at each tourist attraction or in the parking lot when they return to their respective hometowns. Respondents' answers were quantified and measured using a five-category Likert scale ranging from strongly disagree to strongly agree. Furthermore, the data is processed and analyzed using Warp Partial Least Square (Solimun, 2017).

\section{RESULTS AND DISCUSSION}

The characteristics of respondents in this study are tourists who visit Bumiaji tourism village, located in Batu City, Indonesia. Based on gender, $63 \%$ are female and $37 \%$ are male. Based on age criterion, $55 \%$ are $17-25$ years old, $22 \%$ are over 45 years old, $19 \%$ are $26-35$ years old, and $4 \%$ of respondents are 
Table 1. Warp PLS model fit

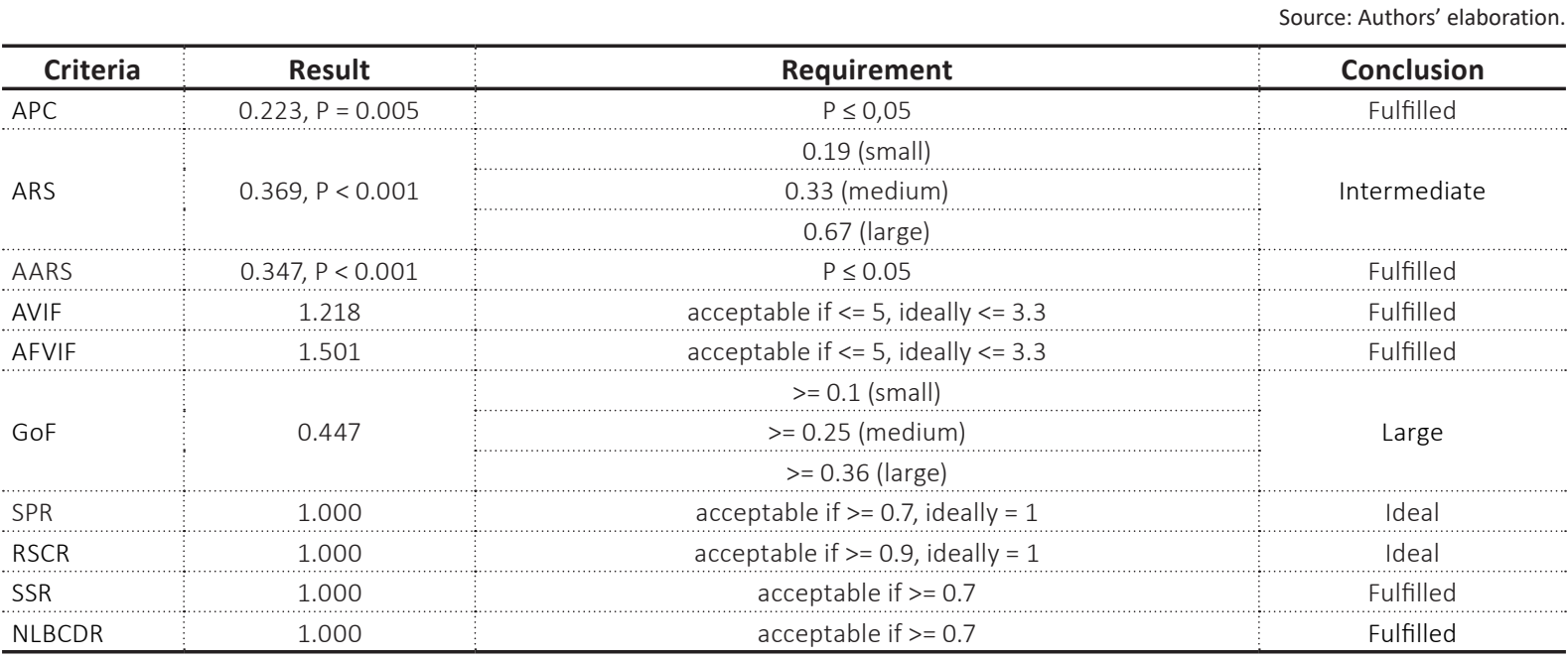

36-45 years old. Based on the education level, $61 \%$ (highest percentage) of respondents had the latest education level of high school/secondary school, $30 \%$ have undergraduate level, $6 \%$ - diploma level, $2 \%$ - postgraduate level, and $1 \%$ - elementary school level. Based on the respondent's work, it is quite evenly distributed from various kinds of professions, in terms of students as much as $38 \%$, private employees as much as $27 \%$, civil servants as much as $18 \%$, self-employed as much as $10 \%$, and other professions as much as $7 \%$. Based on the data it can be said that the respondents used are samples that can present the population, both in terms of gender, age, education, and occupation.

The first step to ensure the feasibility of the model is to evaluate the suitability of the structural model in order to consider the acceptance of the research hypothesis. Verification of the suitability of the model (model fit) is carried out using WarpPLS 6 for the criteria and results of data processing as listed in Table 1.

Based on the data from the analysis as listed in Table 1, it can be concluded that all the criteria have met the requirements, or in other words, there is no multicollinearity. The calculation results, as listed in Table 2, show that the observed values have been reconstructed well as depicted from the value of Q Square.

The criterion for acceptance or rejection of a hypothesis is to pay attention to the p-value, where the hypothesis is accepted if the p-value is less than 0.05 . Based on the data in Table 4, it can be concluded that accessibility has an indirect effect on visiting decisions through tourist motivation. Meanwhile, based on Table 3, it is known that accessibility does not significantly influence the tourist motivation variable so that the tourist motivation variable does not meet the requirements as a mediating variable. The effect of accessibility on visiting decisions is not mediated by the tourist motivation variable. Based on the analysis of the effect of accessibility on tourist motivation, it was found that accessibility had no significant effect on tourist motivation. This means that the better accessibility to and in Bumiaji tourist destinations, such as ease of access, quality of roads, travel time, and availability of public transportation, does not have an impact on increasing the motivation of tourists to visit Bumiaji tourism village. In other words, without any increase in accessibility, the motivation of tourists is still high. The results of this study are not in line with Dey et al. (2020), and Correia and Pimpao (2008), who concluded that accessibility has a significant effect on tourist motivation. Jin and Weber (2016) concluded that visitors prefer tourist destinations with good accessibility and attractive recreational environments. Meanwhile, Díez-Gutierrez and Babri (2020) state that tourists choose their main route based on travel time and road views. Access has a significant positive impact on tourist attitudes (Reitsamer et al., 2016).

The effect of amenities on tourist motivation shows that amenities have a significant effect on 
Source: Authors' elaboration.

\begin{tabular}{|c|c|c|c|}
\hline Model & R Square & Adj. R. Square & Q Square \\
\hline Accessibility, amenities, and attractions $\rightarrow$ Tourist motivation & 0.205 & 0.180 & 0.208 \\
\hline Accessibility, amenities, attractions, and tourist motivation $\rightarrow$ Visiting decision & 0.534 & 0.514 & 0.540 \\
\hline
\end{tabular}

Table 3. First path result

Source: Authors' elaboration.

\begin{tabular}{|c|c|c|c|c|}
\hline Hypothesis & $1^{\text {st }}$ Path & Direct effect & p-Value (Sig) & Info. \\
\hline$H 1$ & Accessibility $\rightarrow$ Tourist motivation & 0.041 & 0.339 & Not Sig. \\
\hline $\mathrm{H} 2$ & Amenities $\rightarrow$ Tourist motivation & 0.183 & 0.029 & Sig. \\
\hline $\mathrm{H3}$ & Attractions $\rightarrow$ Tourist motivation & 0.331 & $<0.001$ & Sig. \\
\hline $\mathrm{H} 4$ & Tourist's motivation $\rightarrow$ Visiting decision & 0.264 & 0.003 & Sig. \\
\hline H5 & Accessibility $\rightarrow$ Visiting decision & 0.203 & 0.017 & Sig. \\
\hline$H 6$ & Amenities $\rightarrow$ Visiting decision & 0.237 & 0.007 & Sig. \\
\hline$H 7$ & Attractions $\rightarrow$ Visiting decision & 0.300 & $<0.001$ & Sig. \\
\hline
\end{tabular}

Table 4. Second path result

Source: Authors' elaboration.

\begin{tabular}{|c|c|c|c|c|c|}
\hline $2^{\text {nd }}$ Path & Direct & Indirect & Total effect & p-Value (Sig) & Info. \\
\hline Accessibility $*$ Tourist motivation $\rightarrow$ Visiting decision & 0.203 & 0.011 & 0.214 & 0.013 & Sig. \\
\hline Amenities * Tourist motivation $\rightarrow$ Visiting decision & 0.237 & 0.048 & 0.285 & 0.001 & Sig. \\
\hline Attractions $*$ Tourist motivation $\rightarrow$ Visiting decision & 0.300 & 0.087 & 0.387 & $<0.001$ & Sig. \\
\hline
\end{tabular}

tourist motivation. Thus, the better the amenities, the higher the motivation of tourists to visit the tourist village of Bumiaji. The results of this study contradict Sarim (2017) who concluded that tourist facilities did not affect the motivation of tourist visits. Meanwhile, according to Spillane (2000), Camilleri (2019), and Reitsamer et al. (2016), basic facilities, such as food, drinks, lodging, gift shops for shopping before returning to their place of origin have a positive and significant effect on attachment formation as these facilities and are found to be the most influencing on the accessibility of visitors (Pratiwi et al., 2015). Tourists looking for an authentic, interesting, and intimate experience, with friends and family, create opportunities for special/ exclusive products (Ponte et al., 2021) Facilities and local communities have a significant positive impact on tourist attitudes (Reitsamer et al., 2016).

There is a positive and significant influence of the attraction variable on the motivation of tourists in Bumiaji tourism village, indicating that if the value of the uniqueness, beauty, and authenticity of the Bumiaji tourism village is maintained and/or increased, it can increase the motivation of tourists to visit this village. This study has extended the study of Dey et al. (2020), Al-Kwifi (2015), and Sudaryanti and Sukriah (2015) who stated that attractive attractions and rural culture have a significant influence on tourist motivation. The results of other studies show that the factors that influence tourists to visit tourist destinations are the friendliness of service providers, the attitudes of local people, local culture, and interesting sights (Hasan et al., 2018). The performance of tourism villages in providing unique local experiences, value for money, and distinctive regional products, and opportunities for entertainment and hunting for bargains are the key variables that most strongly predict whether respondents are very satisfied or not (Murphy et al., 2011).

Accessibility, facilities, and local communities have a significant positive impact on tourist attitudes (Reitsamer et al., 2016). Simeon et al. (2017) revealed five important components of the tourist experience related to cultural attractions. They are magic, authenticity, relaxation, discovery, and knowledge. Wen et al. (2019) showed that tourists can interpret cultural attractions in different ways and cultural values relate to travel motivation. The positive and significant influence of the tourist motivation variable on the decision to visit Bumiaji tourism village shows that increased tourist motivation will improve the decision-making process for tourists. Mohaidin et al. (2017) explained that motivation has a significant effect on tourists' intention to choose sustainable tourist destinations. Meanwhile, Bozic et al. (2017) ex- 
plained that culture is dominant in motivating tourist visits. Kozak and Kozak (2018) explained that tourists who are motivated to make tourist visits are to experience a different culture.

There is a significant influence of accessibility on visiting decisions. The results of this study are in line with the results of previous studies, which state that the accessibility dimension influences visiting decisions because access to tourist attractions according to visitors is quite easy (Trigantiarsyah \& Mulyadi, 2012). Abdulhaji and Yusuf (2016) stated that the accessibility variable plays an important role in achieving access to tourist objects properly. City residents are willing to spend more time traveling to high-quality destinations rich in resource landscapes and recreational facilities (Zhang et al., 2021). Distance and population density show the negative impact of tourist decisions when choosing certain destinations and accessibility as it is an important determinant of tourism flows (Marrocu \& Paci, 2013). There is a significant influence between the amenities on the decision to visit. The availability of tourism support facilities makes tourists feel at home in tourist attractions. Martaleni (2011) explained that supporting facilities are the attention of tourists in visiting a destination. Cakici and Harman (2007) stated that the amenities attribute is one of the factors that encourage tourists to decide to visit a tourist attraction. The relationship of attraction to visiting decisions also has a significant relationship. The findings of this study are in line with Lakhoua et al. (2020) who explained that rational fatalism, compassion, curiosity, and better offering value are the main motivations expressed by tourists visiting tourist destinations. Cakici and Harman (2007) stated that the attraction variable has a dominant and positive influence on destination selection. The culture and authenticity of the destination influence the tourist decision-making process (Lee et al., 2020). For this reason, marketers must focus more effectively on promoting 'local touch' experiences (Dai et al., 2019). Attractions are important determinants of tourism flow (Marrocu \& Paci, 2013).

The accessibility has a positive effect on the decision to visit through the motivation of tourists to Bumiaji tourism village, but it is not significant. This means that motivation is not a mediating variable between accessibility and the decision to visit because it does not meet the mediation requirements. This shows that although there is a positive influence of motivation on the decision to visit, if the accessibility conditions are not good, the motivation to visit also has no effect. The findings of this study are in line with Martaleni (2011), who concluded that supporting facilities are the attention of tourists in visiting tourist destinations. However, when compared with the conclusions of Luo and Ye (2020), the results of the study do not strengthen this conclusion, where the conclusion of Luo and Ye (2020) states that motivation is a mediating variable between generativity and intention to visit. The results showed that the available facilities will motivate tourists to come to visit a tourist attraction. Another finding shows that there is a positive influence of the attraction variable on the decision to visit through the motivation of tourists to visit Bumiaji tourism village, but it is not significant. This means that motivation is a mediating variable between attractions and visiting decisions, which means that the attractions (attractiveness) in tourist objects can attract the motivation of tourists. The results of this study are in line with Martaleni (2012) who also stated that attractions (tourist attractions) provide a high contribution to the quality of service perceived by tourists so that tourists who visit pay attention to the attractions offered. The results showed the relationship of attractions will motivate tourists to come to visit a tourist attraction. One of the key factors that can ensure the sustainability of tourism in a destination is the consistent competitiveness and attractiveness of destinations (Nadalipour et al., 2018).

\section{CONCLUSION}

This study has investigated the role of tourist motivation as a mediation of the influence of accessibility, amenities, and attractions on visitor decisions. The research findings explain that accessibility directly does not have a significant effect on tourist motivation. This means that the better accessibility as indicated by the ease of access, road quality, travel time, and the availability of public transportation in 
the tourist village, does not have an impact on the motivation of tourists to visit. Tourist motivation as indicated by physical, cultural, social, and cultural fantasy motivation does not mediate the relationship between accessibility and visitor decisions. However, the direct relationship between amenities and attractions on visitor decisions has a significant effect. This means increasing amenities and attractions can increase tourist motivation to visit. Further findings explain that tourist motivation can mediate the effect of amenities and attractions on tourist visiting decisions. Meanwhile, accessibility has a direct effect on visitor decisions in the sense that tourist motivation does not mediate the relationship between these two things.

\section{AUTHOR CONTRIBUTIONS}

Conceptualization: Martaleni Martaleni.

Data curation: Ernani Hadiyati.

Formal analysis: Yussi Isna Pertiwi, Ni Nyoman Kerti Yasa.

Investigation: Martaleni Martaleni.

Methodology: Ernani Hadiyati.

Project administration: Yussi Isna Pertiwi.

Resources: Ni Nyoman Kerti Yasa.

Software: Martaleni Martaleni.

Supervision: Ernani Hadiyati.

Validation: Yussi Isna Pertiwi.

Visualization: Ni Nyoman Kerti Yasa.

Writing - original draft: Martaleni Martaleni, Yussi Isna Pertiwi.

Writing - review \& editing: Ernani Hadiyati, Ni Nyoman Kerti Yasa.

\section{REFERENCES}

1. Abdulhaji, S., \& Yusuf, A. S. (2016). Pengaruh Atraksi, Aksesibilitas, Dan Fasilitas Terhadap Citra Objek Wisata Danau Tolire Besar Di Kota Ternate. Jurnal Penelitian Humano, 7(2), 134-148. (In Indonesian). Retrieved from https:// ejournal.unkhair.ac.id/index.php/ humano/article/view/317

2. Aksoy, R., \& Kiyci, S. (2011). A destination image as a type of image and measuring destination image in tourism (Amasra case). European Journal of Social Sciences, 20(3), 478-488. http:// acikarsiv.beun.edu.tr/xmlui/ handle/20.500.12628/3924

3. Albayrak, T., \& Caber, M. (2018). Examining the relationship between tourist motivation and satisfaction by two competing methods. Tourism Management, 69, 201-213. https://doi.org/10.1016/j. tourman.2018.06.015

4. Al-Kwifi, O. S. (2015). The impact of destination images on tourists' decision making: A technologi- cal exploratory study using fMRI. Journal of Hospitality and Tourism Technology, 6(2), 174-194. https:// doi.org/10.1108/JHTT-06-20150024

5. Bayih, B. E., \& Singh, A. (2020). Modeling domestic tourism: Motivations, satisfaction and tourist behavioral intentions. Heliyon, 6(9), E04839. https://doi. org/10.1016/j.heliyon.2020.e04839

6. Beritellia, P., Reinholdb, S., \& Laesser, C. (2020). Visitor flows, trajectories and corridors: planning and designing places from the traveler's point of view. Annals of Tourism Research, 82, 102936. https://doi.org/10.1016/j.annals.2020.102936

7. Bhulyan, M. A. H., \& Darda, M. A. (2020). Tourists' satisfaction on heritage sites of Dhaka City in Bangladesh. International Journal of Culture, Tourism and Hospitality Research, 14(1), 34-43. https://doi.org/10.1108/IJCTHR-06-2018-0081
8. Bideci, M., \& Albayrak, T. (2016). Motivations of the Russian and German tourists visiting pilgrimage site of Saint Nicholas Church. Tourism Management Perspectives, 18, 10-13. https://doi.org/10.1016/j. tmp.2015.12.022

9. Boom Liat, C., Nikhashemi, S. R, \& Dent, M. M. (2020). The chain effects of service innovation components on the building blocks of tourism destination loyalty: The moderating role of religiosity. Journal of Islam Marketing. https:// doi.org/10.1108/Jima-02-20200061

10. Bozic, S., Kennell, J., Vujiv, M. D., \& Jovanovic, T. (2017). Urban tourist motivations: Why visit Ljubljana? International Journal of Tourism, 3(4), 382-398. https://doi. org/10.1108/IJTC-03-2017-0012

11. Buhalis, D. (2000). Marketing the competitive destination of the future. Tourism Management, 21(1), 97-116. https://doi.org/10.1016/ S0261-5177(99)00095-3 
12. Cakici, A. C., \& Harman, S. (2007). Importance of destination attributes affecting destination choice of Turkish birdwatchers. Journal of Commerce \& Tourist Education Faculty, 1, 131-145. https://app.trdizin.gov.tr/makale/ TnpVd09UTXo/importance-ofdestination-attributes-affectingdestination-choice-of-turkishbirdwatchers

13. Camilleri, M. A. (2019). The planning and development of the tourism product. In Tourism Planning and Destination Marketing (pp. 1-23). Emerald Publishing Limited.

14. Celik, S., \& Dedeoglu, B. B. (2019). Psychological factors affecting the behavioral intention of the tourist visiting Southeastern Anatolia. Journal of Hospitality and Tourism Insights, 2(4), 425-450. https://doi. org/10.1108/JHTI-01-2019-0005

15. Correia, A., \& Pimpao, A. (2008). Decision-making processes of Portuguese tourist travelling to South America and Africa. International Journal of Culture Tourism and Hospitality Research, 2(4), 330-373. http://dx.doi. org/10.1108/17506180810908989

16. Cresweel, J. W. (2014). Research Design: Qualitative, Quantitative, and Mixed Methods Approaches ( $3^{\text {rd }}$ ed.). Sage Publications.

17. Dai, T., Hein, C., \& Zhang, T. (2019). Understanding how Amsterdam City tourism marketing addresses cruise tourists' motivations regarding culture. Tourism Management Perspectives, 29, 157-165. https://doi.org/10.1016/j. tmp.2018.12.001

18. Dey, B., Mathew, J., \& Cheen-Hua (2020). Influence of destination attractiveness factors and travel motivations on rural homestay choice: The moderating role of need for uniqueness. International Journal of Culture, Tourism and Hospitality Research, 14(4), 639-666. https://doi.org/10.1108/ IJCTHR-08-2019-0138

19. Díez-Gutierrez, M., \& Babri, S (2020). Explanatory variables underlying the route choice decisions of tourists: The case of Geiranger Fjord in Norway. Transportation
Research Part A: Police and Practice, 141, 398-409. http://dx.doi. org/10.1016/j.tra.2020.09.023

20. Faerber, L. S., Hofmann, J., Ahrholdt, D., \& Schnittka, O. (2021). When are visitors actually satisfied at visitor attractions? What we know from more than 30 years of research. Tourism Management, 84.

21. Gelgel, I. P. (2006). Industri Periwisata Indonesia Dalam Globalisasi Perdagangan Jasa (GATS-WTO). Bandung: Refika Aditama. (In Indonesian).

22. Güzela, O., Sahina, I., \& Ryan, C. (2020). Push-motivation-based emotional arousal: A research study in a coastal destination. Journal of Destination Marketing \& Managemen, 16, 100428 https://doi.org/10.1016/j. jdmm.2020.100428

23. Hair, Jr. J. F., Black, W. C., Babin, B. J., \& Anderson, R. E. (2014). Multivariate data analysis ( $7^{\text {th }} \mathrm{ed}$.). Pearson Education Limited.

24. Hakim, D. H., \& Mulia, D. (2019). The effect of tourism attractiveness, travel motivation, e-WOM on visit decision and satisfaction. International Journal of Business and Management Invention (IJBMI), 8(09), 23-29. Retrieved from http://www.ijbmi.org/papers/ Vol(8)9/Series-2/C0809022329.pdf

25. Happ, E., Hofmann, V., \& Schnitzer, M. (2021). A look at the present and future: The power of emotions in the interplay between motivation, expectation and attitude in long-distance hikers. Journal of Destination Marketing \& Management, 19, 100527. https://doi.org/10.1016/j. jdmm.2020.100527

26. Hasan, T. M. H., Som, A. P. M., \& Ismail, F. (2018). The influence of travel motivation on satisfaction and intention to visit Terengganu. International Journal of Engineering \& Technology, 7(4.34), 480-483. Retrieved from https://www. sciencepubco.com/index.php/ijet/ article/view/27391

27. Hassani, A., \& Moghavvemi, S. (2020). Muslims' travel motivations and travel preferences: the impact of motivational factors on Islamic service, hedonic and product preferences. Journal of Islamic Marketing, 11(2), 344-367. https://doi.org/10.1108/JIMA-112018-0215

28. Hernandez, J. M., Santana-Jimenez, Y., \& Gonzalez-Martel, C. (2021). Factors influencing the co-occurrence of visits to attractions: The case of Madrid, Spain. Tourism Management, 83, 104236 https://doi.org/10.1016/j.tourman.2020.104236

29. Jensen, O., Li, Y., \& Uysal, M. (2017). Visitors' satisfaction at managed tourist attractions in Northern Norway: Do on-site factors matter? Tour ism Management, 63, 277-286. https://doi.org/10.1016/j.tourman.2017.06.025

30. Jin, X. \& Weber, K. (2016). Exhibition destination attractiveness - organizers' and visitors' perspectives. International Journal of Contemporary Hospitality Management, 28(12), 27952819. https://doi.org/10.1108/ IJCHM-01-2015-0023

31. Karayilan, E., \& Cetin, G. (2016). Tourism destination: Design of experiences. In M. Sotiriadis \& D. Gursoy (Eds.), The Handbook of Managing and Marketing Tourism Experiences. Emerald.

32. Kastenholz, E., Eusébio, C., \& Carneiro, M. J. (2018). Segmenting the rural tourist market by sustainable travel behaviour: Insights from village visitors in Portugal. Journal of Destination Marketing \& Management, 10, 132-142. https://doi.org/10.1016/j. jdmm.2018.09.001

33. Kotler, P., \& Keller, K. L. (2016). Marketing Management. New Jersey: Pearson Education.

34. Kotler, P., Bowen, J. T., \& Make, J. C. (2014). Marketing for Hospitality and Tourism ( $6^{\text {th }}$ ed.). USA: Pearson New International Edition.

35. Kozak, M. (2002). Comparative analysis of tourist motivations by nationality and destinations. Tourism Management, 23(3), 221-232. https://doi.org/10.1016/S02615177(01)00090-5 
36. Kozak, M., \& Kozak, N. (2018). Tourist Behavior: An Experiential Perspective. Switzerland: Springer International Publishing.

37. Lakhoua, C., Temessek, A., \& Baccouche, M. K. (2020). Image formation in a destination threatened by terrorism: understanding the role of motivations. Qualitative Market Research. https://doi. org/10.1108/QMR-02-2020-0018

38. Lee, C. K., Ahmad, M. S., Petrick, J. F., Park, Y-N., Park, E., \& Kang, C-W. (2020). The roles of cultural worldview and authenticity in tourists' decision-making process in a heritage tourism destination using a model of goal-directed behavior. Journal of Destination Marketing \& Management, 18, 100500. http://dx.doi.org/10.1016/j. jdmm.2020.100500

39. Lee, C-F. (2015). Tourist satisfaction with factory tour experience. International Journal of Culture, Tourism and Hospitality Research, 9(3), 261-277. https://doi.org/10.1108/IJCTHR-02-2015-0005

40. Luo, J. M., \& Ye, B. H. (2020). Role of generativity on tourists' experience expectation, motivation and visit intention in museums. Journal of Hospitality and Tourism Management, 43, 120-286. https://doi.org/10.1016/j. jhtm.2020.03.002

41. Mak, J. (2004). Tourism And The Economy-Understanding The Economics Of Tourism. University Of Hawaii Press.

42. Malhotra, N. K. (2007). Marketing Research: An Applied Orientation. Pearson Prentice Hall.

43. Marrocu, E., \& Paci, R. (2013). Different tourists to different destinations. evidence from spatial interaction models. Tourism Management, 39, 71-83. https://doi.org/10.1016/j.tourman.2012.10.009

44. Martaleni, M. (2011). Image Daerah Tujuan Wisata: Suatu Tinjauan dari Perspektif Wisatawan Nusantara. Jurnal Ekonomi dan Manajemen, 15(4), 501-522. (In Indonesian). https://doi. org/10.24034/j25485024.y2011. v15.i4.167
45. Martaleni, M. (2014). Pengaruh Motivasi, Kualitas Layanan, Dan Kepuasan Wisatawan Terhadap Image Daerah Tujuan Wisata. Jurnal Ekonomi Dan Keuangan, 18(2), 201-218. (In Indonesian). https:// doi.org/10.24034/j25485024.y2014. v18.i2.145

46. Martaleni, M. (2017). International research and development for human beings. Malang: Irish Publishing.

47. Martaleni, M., \& Gunadi, G. (2017). Analysis of tourism destination image attributes: A case of Batu City, Indonesia. Middle-East Journal of Scientific Research, 25(5), 1136-1142.

48. Martaleni, N., Joesoef, J. R., \& Wahyono, G. B. (2019). Halal Tourism Potential: An Investigation in Bromo Tengger Indonesia. Revista San Gregorio, 34, 89-107. Retrieved from http://revista. sangregorio.edu.ec/index.php/REVISTASANGREGORIO/article/ view/1167/11-NIK

49. Mohaidin, Z., Wei, K. T., \& Murshid, M. A. (2017). Factors influencing the tourists' intention to select sustainable tourism destination: A case study of Penang, Malaysia. International Journal of Tourism Cities, 3(4), 442-465. https://doi.org/10.1108/IJTC-112016-0049

50. Moutinho, L. (1987). Consumer behaviour in tourism. European Journal of Marketing, 21(10), 5-44. http://dx.doi.org/10.1108/ EUM0000000004718

51. Murphy, L., Moscardo, G., \& Benckendorff, P. (2011). Evaluating tourist satisfaction with the retail experience in a typical tourist shopping village. Journal of Retailing and Consumer Services, 18(4), 302-310. https://doi.org/10.1016/j. jretconser.2011.02.004

52. Nadalipour, Z., Khoshkho, M. H., \& Eftekhari, A. R. (2018). An integrated model of destination sustainable competitiveness. Competitiveness Review, 29(4), 314-335. https://doi.org/10.1108/CR-122017-0086

53. Pitana, I. G., \& Dianta, K. S. (2009). Pengantar Ilmu Pariwisata.
Yogyakarta: Andi Offset.

54. Pizam, A., Neumann, Y., \& Reichel, A. (1979). Tourist satisfaction: Uses and misuses. Annals of Tourism Research, 6(2), 195-197. https://doi.org/10.1016/01607383(79)90146-4

55. Pololikashvili, Z. (2019). International tourism continues to outpace the global economy. Unwto. Retrieved from https://www.unwto.org/international-tourismgrowth-continues-to-outpace-theeconomy

56. Ponte, J., Couto, G., Sousa, A., Pimentel, P., \& Oliveira, A. (2021). Idealizing adventure tourism experiences: Tourists' self-assessment and expectations. Journal of Outdoor Recreation and Tourism, 35, 100379. https://doi. org/10.1016/j.jort.2021.100379

57. Pratiwi, A. R., Zhao, S., \& Mi, X. (2015). Quantifying the relationship between visitor satisfaction and perceived accessibility to pedestrian spaces on festival days. Frontiers of Architectural Research, 4(4), 285-295. https://doi. org/10.1016/j.foar.2015.06.004

58. Preko, A., Doe, F., \& Dadzie, S. A. (2019). The future of youth tourism in Ghana: motives, satisfaction and behavioural intentions. Journal of Tourism Futures, 5(1), 5-21. https://doi.org/10.1108/JTF12-2016-0059

59. Quintal, V. A. \& Polczynski, P. (2010). Factors influencing tourists' revisit intentions. Asia Pacific Journal of Marketing and Logistics, 22(4), 554-578. http://dx.doi. org/10.1108/13555851011090565

60. Reitsamer, B.F., Brunner-Sperdin, A. B., \& Stokburger-Sauer, N. E. (2016). Destination attractiveness and destination attachment: The mediating role of tourists' attitude. Tourism Management Perspectives, 19(A), 93-101. https://doi. org/10.1016/j.tmp.2016.05.003

61. Rodrigues, V. M. J., Carneiro, M. J., Eusebio, C., Madaleno, M., Robaina, M., Gama, C., Oliveira, K., Relvas, H., Lopes, M., \& Monteiro, A. (2021). How important is air quality in travel decision-making? Journal of Outdoor Recreation and 
Tourism, 35, 100380. https://doi. org/10.1016/j.jort.2021.100380

62. Sarim, W. (2017). Pengaruh Fasilitas Wisatawan Terhadap Motivasi Kunjungan Wisatawan (Studi Kasus Kunjungan Wisatawan Kota Solo). Jurnal Hospitality Dan Pariwisata, 3(2), 294-374. Retrieved from https://journal.ubm.ac.id/ index.php/hospitality-pariwisata/ article/download/1339/1150

63. Seo, S., Kim, S., \& Jang, J. (2018). Uncertainty avoidanceas a moderator for influences on foreign resident dining out behaviors. International Journal of Contemporary Hospitality Management, 30(2), 900-918. https://doi.org/10.1108/ IJCHM-03-2016-0152

64. Shakoori, A., \& Hosseini, M. (2019). An examination of the effects of motivation on visitors' loyalty: Case study of the Golestan Palace, Tehran. Tourism Management Perspectives, 32, 100554. https://doi.org/10.1016/j. tmp.2019.100554

65. Shaykh-Baygloo, R. (2021). Foreign tourists' experience: The tri-partite relationships among sense of place toward destination city, tourism attractions and tourists' overall satisfaction - evidence from Shiraz, Iran. Journal of Destination Marketing \& Management, 19.

66. Sie, L., Pegg, S., \& Phelan, K. V. (2021). Senior tourists' self-determined motivations, tour preferences, memorable experiences and subjective well-being: An integrative hierarchical model. Journal of Hospitality and Tourism Management, 47, 251-351. https://doi. org/10.1016/j.jhtm.2021.03.006

67. Simeon, M. I., Buonincontri, P., Cinquengrani, F., \& Martone, A. (2017). Exploring tourists' cultural experiences in Naples through online reviews. Journal of Hospitality and Tourism Technology, 8(2), 220-238. https://doi.org/10.1108/ JHTT-10-2016-0067

68. Solimun, Nurjannah, \& Fernandes, A. A. R. (2017). Metode Statistika Multivariat Pemodelan Persamaan Struktural (Sem) Pendekatan Warppls. Malang: Ub Press. (In Indonesian).
69. Spillane, J. (2000). Ekonomi Pariwisata: Sejarah Dan Prospeknya. Yogyakarta: Kanisius.

70. Sudaryanti, I. J., Sukriah, E. R. (2015). Analisis Faktor-Faktor Yang Mempengaruhi Motivasi Wisatawan Dalam Melakukan Wisata Heritage Di Kawasan Braga Kota Bandung. Jurnal Manajemen Resort \& Leisure, 12(1), 43-56. (In Indonesian). Retrieved from https://ejournal.upi.edu/index. php/jurel/article/view/1047

71. Tajzadeh, A. A. N. (2013). Value creation in tourism: An Islamic approach. International Research Journal of Applied and Basic Sciences, 4(5), 1252-1264. Retrieved from https://www.cabdirect.org/ cabdirect/abstract/20133337508

72. Teixeira, S. J., Ferreira, J. J. M., Almeida, A., \& Parra-Lopez, E. (2019). Tourist events and satisfaction: A product of regional tourism competitiveness. Tourism Review, 74(4), 943-977. https://doi. org/10.1108/TR-12-2018-0181

73. Trigantiarsyah, R., \& Mulyadi, $H$. (2012). Pengembangan Produk Wisata Dengan Menggunakan Teknik Tourism Opportunity Spectrum Terhadap Keputusan Berkunjung (Survey Pada Pengunjung Cukang Taneuh/Green Canyon Kabupaten Ciamis). Tourism And Hospitality Essentials Journal, 2(1), 201-209. (In Indonesian). Retrieved from https://ejournal.upi. edu/index.php/thejournal/article/ view/1901

74. Tverijonaitea, E., Ólafsdóttira, R., \& Thorsteinsson. T. (2018). Accessibility of protected areas and visitor behaviour: A case study from Iceland. Journal of Outdoor Recreation and Tourism, 24, 1-10. https://doi.org/10.1016/j. jort.2018.09.001

75. Vareiro, L., Sousa, B. B., \& Silva, S. S. (2021). The importance of museums in the tourist development and the motivations of their visitors: An analysis of the Costume Museum in Viana Do Castelo. Journal of Cultural Heritage Management and Sustainable Development, 11(1), 39-57. https://doi.org/10.1108/ JCHMSD-05-2020-0065
76. Volgger, M., Erschbamer, G., \& Pechlaner, H. (2021). Destination design: New perspectives for tourism destination development. Journal of Destination Marketing \& Management, 19, 100561. https://doi.org/10.1016/j. jdmm.2021.100561

77. Wang, J., Luo, L., Huang, S., \& Yang, R. (2020). Restoration in the exhausted body? Tourists on the rugged path of pilgrimage: Motives, experiences, and benefits. Journal of Destination Marketing \& Management, 15, 100407. https://doi.org/10.1016/j. jdmm.2019.100407

78. Wen, J., Huang, S., \& Ying, T. (2019). Relationships between Chinese cultural values and tourist motivations: A study of Chinese tourists visiting Israel. Journal of Destination Marketing \& Management, 14, 100367. http://dx.doi. org/10.1016/j.jdmm.2019.100367

79. Wijaya, S., Wahyudi, W., Kusuma, C. B., \& Sugianto, E. (2019). Travel motivation of Indonesian seniors in choosing destination overseas. International Journal of Culture, Tourism and Hospitality Research, 12(2), 185-197. https://doi.org/10.1108/IJCTHR-09-2017-0095

80. Zhang, J., Cheng, Y., \& Zhao, B. (2021). How to accurately identify the underserved areas of peri-urban parks? An integrated accessibility indicator. Ecological Indicators, 122, 107263. https://doi. org/10.1016/j.ecolind.2020.107263 